\title{
Agricultural risk modelling to improve market information systems in developing countries
}

\section{Oscar Vergara \\ Heidi Wang \\ Gerhard Zuba}

AIR Worldwide

131 Dartmouth Street

Boston

MA 02116

USA

<overgara@air-worldwide.com>

$<$ hwang@air-worldwide.com>

$<$ gzuba@air-worldwide.com >

\begin{abstract}
Agricultural risk modelling can be incorporated into market information systems to provide additional information to farmers, traders, donors, and policy makers in developing countries for better agricultural risk management. The experience gained from developing agricultural risk models for the crop insurance sectors of the United States and China allows AIR to describe the model components and data sources needed for the development of similar models for other regions. This paper discusses examples of situations in which agricultural risk modelling can improve the market information provided to farmers and other stakeholders in developing countries.
\end{abstract}

Key words: crop production; insurance; market information services; probability analysis; risk management; weather.

Subjects: economy and rural development; tools and methods.

\section{Résumé}

Modélisation des risques agricoles pour l'amélioration des systèmes d'information de marché dans les pays en développement

La modélisation des risques agricoles peut être incorporée aux systèmes d'information de marché pour fournir une information additionnelle aux producteurs, commerçants, bailleurs de fonds et décideurs politiques des pays en développement, afin de permettre une meilleure gestion des risques. L'expérience acquise en matière de développement de modèles de risques agricoles pour le secteur des assurances aux États-Unis et en Chine nous permet de spécifier les composantes du modèle et les sources de données nécessaires pour développer des modèles similaires dans d'autres régions. L'article présente des exemples de situations dans lesquelles la modélisation des risques agricoles peut améliorer l'information de marché fournie aux producteurs et aux autres opérateurs dans les pays en développement.

Mots clés : analyse de probabilité ; assurance ; climat ; gestion du risque ; production agricole ; service d'information de marché.

Thèmes : économie et développement rural ; méthodes et outils.
Reprints: O. Vergara

doi: 10.1684/agr.2014.0712
To cite this article: Vergara O, Wang H, Zuba G, 2014. Agricultural risk modelling to improve market information systems in developing countries. Cah Agric 23: 310-6. doi : 10.1684/agr.2014.0712 rom a risk management point of view, few lines of business are as complex and challenging as agricultural production in developing countries. Contrary to commercial agriculture in developed countries that offers producers and farm managers a vast network of public and private market information systems to choose from (Vergara et al., 2005), farmers in developing countries are more dependent on market information services funded by their own contributions and contributions from 
governments and donors, which do not always provide the appropriate and timely information that they need.

In the past decade, a new generation of low-cost market information systems have been developed to serve farmers in several regions of Latin America, Africa, and Asia (FAO, 2005). This new generation of market information systems takes advantage of information and communication technologies such as FM radios, mobile telephones, and the internet to enable farmers in developing countries to monitor and adjust to dynamic market conditions in local, national, and export markets (FAO, 2005; Aker, 2008; Ferris et al., 2008; Svensson and Yanagizawa, 2009). For example, the Zambia National Farmers Union (ZNFU) market information system provides access to weather information to its members through a link to the Zambia Meteorological Department website (ZNFU 2013). The ZNFU is also working on an information platform that uses mobile phones to provide timely information to farmers on the best planting and harvesting dates based on accurate weather forecasts. Also, within the Market Information Organization of the Americas (MIOA 2013), several country-specific market information systems update farmers with market information, weather forecasts, and local commodity prices on a daily basis. The Agricultural Products Market Information System of Honduras (SIMPAH 2013) is an excellent example of this. However, these technological innovations in market information have not been able to help farmers in developing countries protect themselves from the market-distorting effects of widespread crop losses due to weather events, such as major droughts or floods. Given the high severity and low frequency of these catastrophic weather events, they are difficult to forecast. Also, due to the adverse impact the price and yield volatility (created by these catastrophic weather events) can have on the well-being of farmer households (Chapoto et al., 2010), there is a need for farmers and their support organizations to better understand the potential extent of the weather damage to their crops, as well as their potential crop losses, and to then relay this information to governments, policy makers, extension ser- vices, donors, and other farmers in a timely fashion to adjust their risk management strategies accordingly (Jaffee et al., 2010). This can be achieved through modelling the impact of weather on crop development and the end of the season yield, and to provide an early assessment of potential financial loss that will allow farmers and their support networks to mitigate the risk.

This paper discusses the way in which agricultural risk modelling can be used as part of a market information system for producers in developing countries. Because we are not aware of any market information system operating in a developing country that also incorporates agricultural risk modelling for risk management, we will use examples of successful programs currently operating in the United States. First, we will discuss the types of data that can be generated by agricultural risk modelling and how farmers can derive maximum value from it. Second, we will describe the components of the agricultural risk model developed by AIR for the United States and China crop insurance sector, and the sources of information available to develop similar models for developing countries.

\section{Uses of agricultural risk models as part of market information}

\section{systems}

For agricultural production systems around the world, weather is the number one peril. Droughts and floods account for the bulk of crop losses for both irrigated and nonirrigated production systems. Given the importance of weather risk in crop production, it is necessary to model its impact on crop yield losses as accurately as possible.

We are not aware of any market information system operating in a developing country that also incorporates weather modelling for risk management. Perhaps the best example of a successful market information system that combines weather information, crop yield modelling, agricultural market intelligence, commodity pricing, and agricultural finance and insurance is FARMDOC (FARMDOC, 2013), managed by the Department of Agricultural and Consumer Economics at the University of Illinois and funded by a government/private donor partnership. FARMDOC has a broad readership among farmers and ranchers in the United States and is also a trusted source of information for agricultural risk managers looking for information on commodity markets, expected crop insurance payouts given current yields and prices, and local weather conditions.

In this paper, we propose a market information system for farmers in developing countries in which weather risk modelling plays a central role. Figure 1 shows the principal components of the proposed model. The primary purpose of agricultural risk modelling is to provide estimates (to farmers, donors, policymakers, financial institutions, and government agencies) of the agricultural portfolio loss potential due to adverse weather events. This estimation provides a critical tool to provide information to farmers and the rest of stakeholders that will allow them to optimize risk management strategies, such as those described below.

\section{Planting and harvesting decisions}

Weather and crop yield forecasts are very important since they allow farmers to make better planting and harvesting decisions. For example, in non-irrigated agricultural systems in sub-Saharan Africa, near-term weather variability and long-term climate change are the major influences of production variability (Hagbladde et al., 2009). In areas in which the crop growing season is short or prone to droughts and/or floods, farmers would benefit from timely and accurate weather information provided by agricultural risk models that allow them to choose the better planting and harvesting period to minimize production risk and maximize returns.

\section{Input usage}

If weather forecasts point at a great start for the growing season, farmers 


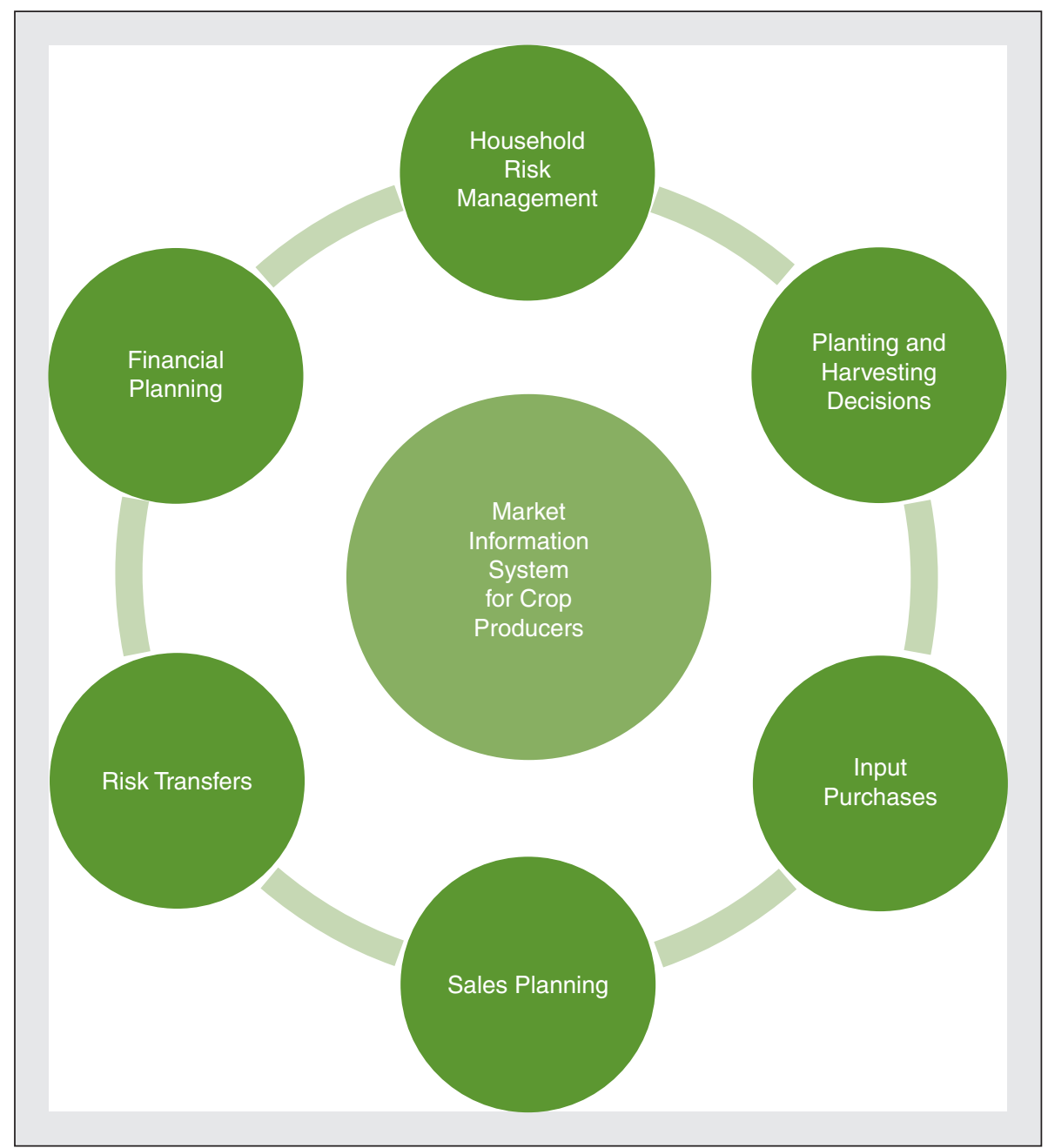

Figure 1. Components of a weather-based market information system for farmers in developing countries.

Figure 1. Composantes d'un système d'information de marché basé sur la météo dans les pays en développement.

Source: AIR.

may increase the amount of technological inputs they use in their production systems in order to increase expected harvested output. Conversely, if the weather forecast shows a detrimental growing season, farmers may choose not to use expensive inputs such as fertilizer and improved seeds that require adequate growing conditions to realize its full potential.

\section{Sales planning}

If the weather and yield forecasts point at a bumper crop scenario, farmers may prepare ahead for the possibility that a grain glut may depress prices in
Simulating thousands of years of yield and price event scenarios, agricultural risk models compute loss distributions and provide exceedance probability curves, similar to the one shown in figure 2.

For example, for this hypothetical region, farmers have a $4 \%$ probability of experiencing roughly a \$50-million agricultural loss this year, which is also equivalent to a 20-year return period loss for this region. The most rare and devastating events this region may face (such as widespread droughts or floods) will fall at the tail end of the probability loss distribution. For example, the worst loss (corresponding to the 1000-year return period) is approximately $\$ 320$ million, which is equivalent to a $0.1 \%$ probability of occurrence. Catastrophic events of even higher magnitudes are relatively frequent around the world. For example, the 1982-1984 drought that affected Zimbabwe at an estimated cost of $\$ 2.5$ billion, or the 1984 Ethiopia and 1985 Sudan droughts that killed 300,000 and 150,000 people, respectively (Vos et al., 2010).

Underwriters at crop insurance companies or NGOs that provide farmers with loss protection against catastrophic weather events use the model results to negotiate the appropriate level of insurance required, given the risk of loss of this portfolio. On the other hand, underwriters at reinsurance companies use the same model results to price the required protection at a rate that reflects the potential weather risk affecting this region.

\section{Financial planning}

Accurate weather and yield estimates allow for better farm budgeting and financial planning of expected income and expenses. This would increase the possibility for farmers to access financial markets and seek formal credit, or to better negotiate interest rates and loan repayment options if they tap informal lending sources.

\section{Risk transfers}

For farmers, traders, or an NGO interested in protecting the agricultural portfolio of a farming community, agricultural risk modelling represents the best way to determine the necessary insurance coverage.

\section{Farm risk management}

Ultimately, the goal of market information systems, that include information on catastrophic weather and yield event scenarios, is to ensure the financial stability of farmers when 


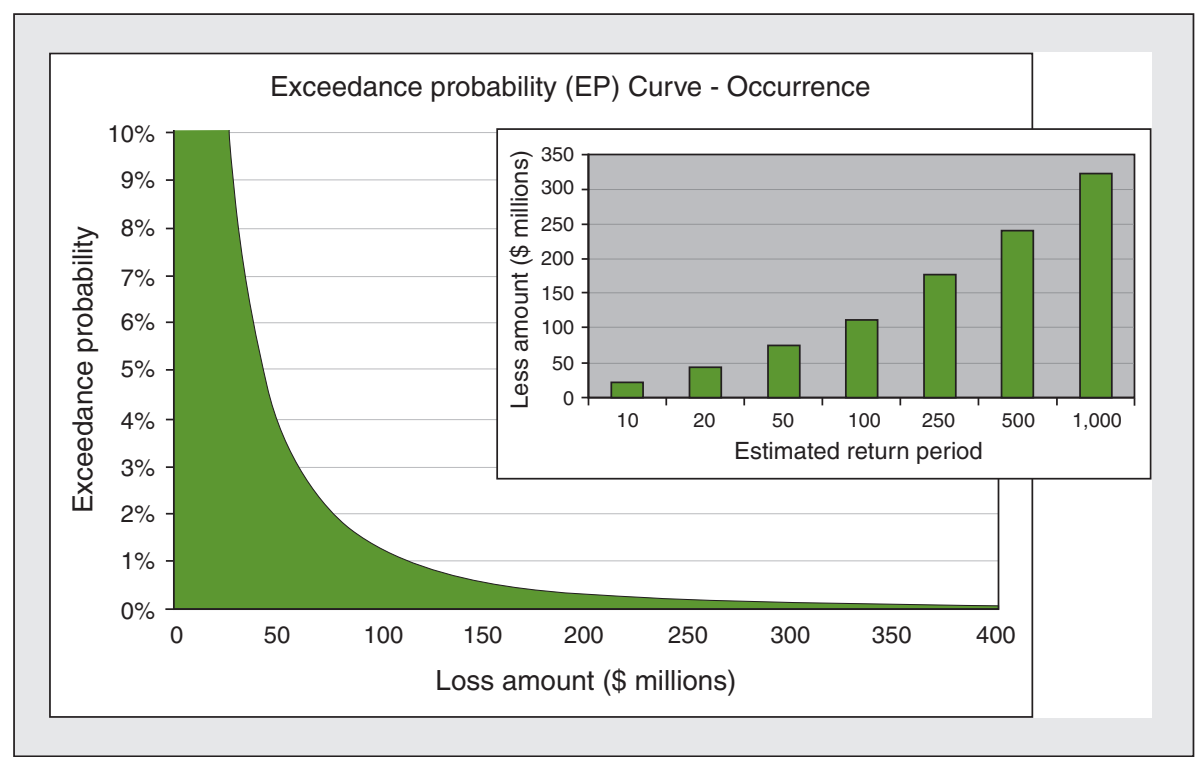

Figure 2. Example of exceedance probability curve.

Figure 2. Exemple de courbe de probabilité de dépassement.

Source: AIR.

disasters strike. Decisions on insurance purchases or credit applications, on-farm versus off-farm labour considerations, staying in an area or relocating to other less affected areas, expanding or contracting production, storing or selling additional production, among others, can be influenced by catastrophic event simulations.

\section{Components of an agricultural risk model}

Following a schematic framework developed by AIR (2009; 2011), figure 3 shows the principal components of an agricultural risk model.

\section{Hazard component}

The hazard component involves quantifying the impact weather risk has on the historical crop yield data using an Agricultural Weather Index (AWI ${ }^{\mathrm{TM}}$ ) model (AIR, 2005). The AWI model is crop- and county-specific and uses high-resolution gridded daily temperature and precipitation data available from the National Center for Environmental Prediction (NCEP) that is coupled with high-resolution soil data available from the United information is combined with crop-
specific data to produce a water

States Geological Survey. The weather and soil data is available on a global scale at different levels of resolution. In general, we have found that a 50 $\mathrm{km}$ grid provides a meaningful level of resolution for agricultural risk analysis. Within each grid, the weather and soil information is combined with crop- balance model that correlates water availability to crops during the growing season with the crop requirements based on phenological information from experimental stations, extension services, or local farming experience. The end result is to produce a single index value that condenses all the weather effects experienced by a crop in the field into a single index number that is a qualifier of how good (or detrimental) the entire growing season has been for crops and its influence in the yield outcome. There is one AWI value per county and crop, for each year over the last 36 years in our database. The AWI value is later on used as a weather correction to properly detrend the historical yield time series. After detrending, crop yield distributions are fitted to the historical yield data to be then used in agricultural portfolio risk analysis (Vergara et al., 2008).

The advantage of the AWI-based yield distributions over other types of models proposed by the agricultural economics literature (Ker and Goodwin, 2000; Ramirez et al., 2003; Sherrick et al., 2004) is that, by construction, they are more suitable to assess weather-derived crop yield losses, thus being less biased with respect to over-estimation or underestimation of the county's yield trend.

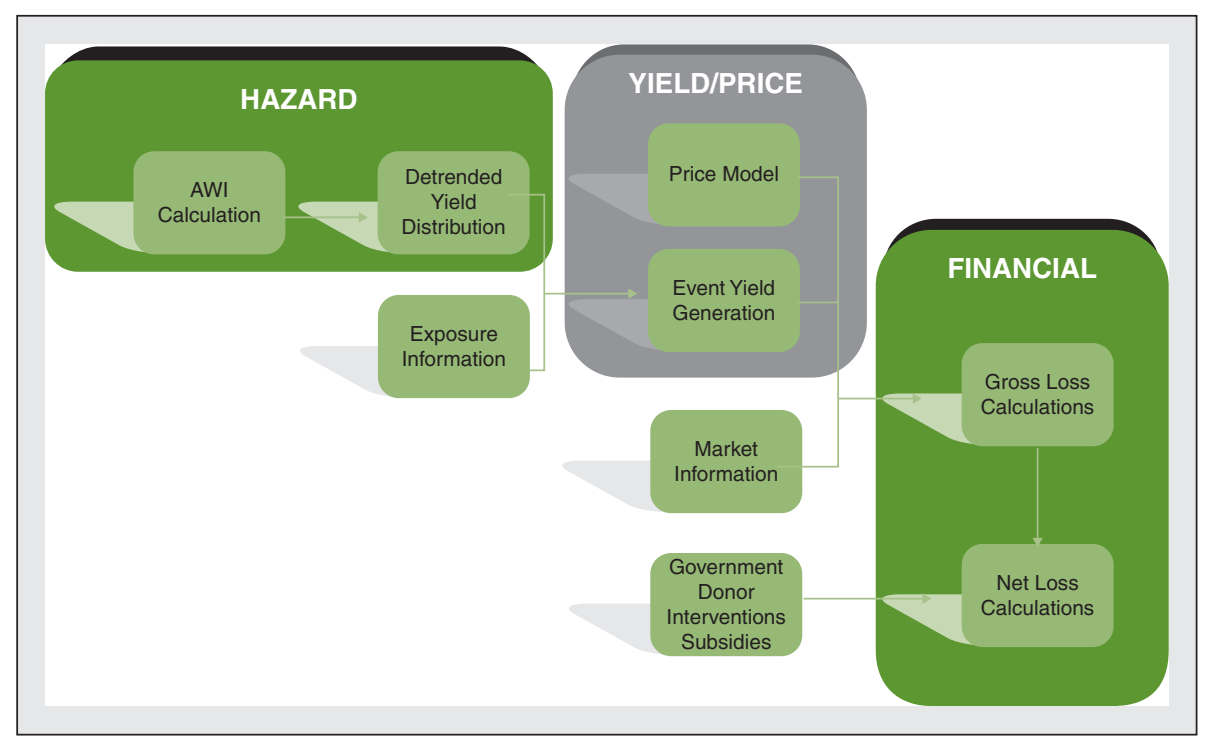

Figure 3. Components of an agricultural risk model.

Figure 3. Composantes d'un modèle de risques agricoles. Source: AIR. 


\section{Yield/price component}

In addition to yield modelling, a price modelling component is necessary to account for the revenue risk proportion of an agricultural portfolio, as well as spikes in commodity price volatilities commonly observed in the future markets due to speculation (Trostle, 2008). Generally speaking, a simple price model will look at the historical relationship between the planting and harvesting prices and the nationwide crop yields. The yield and price distributions are jointly combined to construct a stochastic event catalogue of 10,000 loss event scenarios using Monte Carlo techniques. The county loss event scenarios are aggregated at the state level and nationwide level to provide 10,000 stochastic yield and price scenarios that are equally likely to occur next year.

When compiling the stochastic event catalogue for a region or an entire country, a critical process is to make sure that the natural crop yield correlation between neighbouring counties and between crops within a county is maintained. This is a key step that can only be done through modelling the impact of weather on crop yields. Capturing the yield correlations allows for a better understanding of crop portfolio risk and decision planning. For example, the African Risk Capacity project of the African Union and the World Food Programme require that member countries pool economic resources to compensate farmers in countries that are affected by drought, when others are not, in a given year. A good understanding of weather and yield correlation is basic to assess the likelihood of droughts and to compute the pool portfolio risk given the diversification in the performance of rainfall seasons across Africa (African Risk Capacity, 2013).

\section{Financial component}

Here, any future sale contractual obligations (in the case of spot or forward contracts) or policy conditions (in the case of crop insurance contracts) are applied to the modelled yield and price scenarios on a countyby-county basis in the stochastic event catalogue to calculate the potential portfolio losses. These are aggregated at the state or regional level in order to quantify the gross losses from an agricultural portfolio. The portfolio losses are also reported on a net basis once donor transfers, government programs, or subsidies to palliate farmers' losses have been accounted for. The portfolio loss calculation output provides decision makers with a range of potential losses and the corresponding probability that each level of loss will occur. The information is presented as exceedance probability curves and as average annual losses.

\section{Development of agricultural risk models for developing countries}

Every year, farmers in developing countries alter the crop exposure landscape by choosing to plant, more or less, a particular crop; a choice that is guided, for the most part, by the household annual consumption needs, availability of on-farm and off-farm work, and the expectation of the highest profit they can obtain at harvest time from the portion of the crop that will be sold (Vergara et al., 2004).

Technological improvements have increased the ability of crops to recover and produce average yields, even after a growing season that got off to a bad start. The accumulated effect of adverse weather during the growing season will not be known with certainty until harvest time, once the crop is harvested, weighed, and marketed.

Because losses in agricultural production areas are spatially correlated, catastrophic weather events, such as droughts or floods, will trigger widespread losses to farmers in the affected region. Eventually, if the pervasive weather conditions persist, crops will fail entirely and governments and donors will have to allocate resources for humanitarian aid and recovery (World Food Programme, 2012).

There has been a great amount of field work done in several developing countries to understand the impact adverse weather has on the well-being of farmers and to study mechanisms to transfer risk outside of the farming sector. A document by the World Bank's Agriculture and Rural Development Group lists all the pilot programs undertaken and the experiences learned from modelling weather risk in Malawi, Kenya, Ethiopia, Tanzania, and Burkina Faso (Jaffee et al., 2008). Another paper by Collier et al. (2010) provides a primer on catastrophic risk modelling of weather events for insurance purposes around the world.

In order to quantify weather risk to crop portfolios in developing countries, data is required to fit the yield loss models. The AIR model for the United States (AIR, 2009) and China (AIR, 2011) currently uses the following data layers: weather information (precipitation, temperature); soil information (soil classification, land use, irrigation, crop moisture index); crop information (crop types, phenological stages, production practices); price information (farm level prices, market prices, production costs); production information (area planted, area harvested, yields); loss information (according to type of weather perils, insured losses, non-insured losses); and socio-economic information (farm typology, farmer characteristics). This information is available on a global scale at different levels of resolution (most commonly county and/or state).

The AIR agricultural modelling team has collected data on hundreds of historical drought, flood, and typhoon events around the world. AIR relies on information from agencies that gather original daily temperature and precipitation data, radar data, actual wind records from weather service stations, and wind reports. This information is then coupled with historical crop phenological data, as well as soil, terrain/elevation, and land use/land cover data, to determine the extent of these events.

For developing countries, the weather and yield loss models will be based on historical data from a variety of sources. The primary sources are:

- China Meteorological Administration (CMA)

- Climate Prediction Center (NOAA/ $\mathrm{CPC})$ 
- Food and Agricultural Organization (FAO)

- Goethe University (MIRCA)

- Africa Soil Information Service (AfSIS) ${ }^{1}$

- International Soil Reference and Information Centre (ISRIC)

- Japan Meteorological Agency (JMA)

- National Bureau of Statistics of China

- Shanghai Typhoon Institute (STI)

- Tropical Rainfall Measuring Mission (TRMM)

- United States Geological Survey (USGS)

- Earth Resources Observation and Science (EROS) Center

Additional sources of data are also available from international research centers, NGOs, and universities that are conducting field research in developing countries.

\section{Model application for agricultural risk management}

As indicated before, AIR has released agricultural risk models for the United States and China which are currently the leading models used by the crop insurance and reinsurance industry to quantify crop portfolio losses. In both the United States and China, more than 90\% of crop losses are caused by adverse weather events, including drought, flooding, hail, frost, and windstorm. In the past, estimating the likelihood and magnitude of future crop losses has presented significant challenges. Forecast models are not capable of predicting with certainty average temperature and precipitation levels beyond a few days in advance, let alone the detailed weather patterns during the most critical times of crop production. To estimate yields, AIR uses a weather-based approach that correlates the amount of water available to crops during the growing season with how much water a particular crop requires. AIR closely monitors each growing season and

\footnotetext{
${ }^{1}$ We thank our reviewer for pointing out this important source of continent-wide digital soil maps for sub-Saharan Africa available at http:// www.africasoils.net/home
}

provides detailed information on industry-wide corn and soybean production and potential losses through the CropAlert ${ }^{\circledR}$ Growing Conditions Report $^{2}$.

Issued every month from June through to October, CropAlert provides farmers, commodity traders, agribusinesses, farm managers, and crop insurers and reinsurers with AIR's crop yield estimates based on season-to-date weather observations calculated with AIR's Agricultural Weather Index (AWI). County- and crop-specific, the AWI is used to assess the overall quality of the growing season. CropAlert includes a discussion on how precipitation, temperature, and soil conditions may impact different crops in various parts of the United States at specific stages of growth.

CropAlert also shows AIR's current corn and soybean yield forecasts in eight key states as well as the United States total, alongside World Agricultural Supply and Demand Estimates (WASDE) and National Agricultural Statistics Service (NASS) yield forecasts, as they become available. CropAlert includes four vivid maps of the United States that illustrate the following aspects of crop growing conditions: Crop Moisture Index, weekly accumulated precipitation, accumulated growing degree days, and weekly average temperature anomaly. CropAlert also includes a discussion section on current weather events that are affecting agricultural production in China and estimates of damage area and crop portfolio losses in real time.

AIR is currently working on additional agricultural risk models for India, Canada, and South America, to be released in the future.

\section{Conclusion}

Agricultural risk modelling can be used as a planning tool to anticipate the likelihood and severity of potential future weather-based catastrophic events, ultimately permitting farmers, governments, policy makers, and the donor community to better prepare for the financial impact of natural

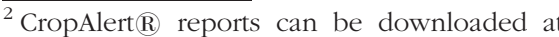
http://www.air-worldwide.com/Models/Crop/ CropAlert/
}

disasters affecting the agricultural sector of developing countries. The inclusion of agricultural risk modelling output (weather and yield forecast, as well as agricultural loss scenarios), as part of the information disseminated by market information systems, will benefit farmers, policymakers, and other end users of the information in developing countries.

\section{References}

African Risk Capacity, 2013. African Risk Capacity. Sovereign disaster risk solutions: a project of the African Union. Johannesburg (South Africa): African Union. http://unfccc.int/files/adaptation/application/pdf/african risk capacity fatima kassam. pdf

AIR Worldwide Corporation, 2005. Using the $A / R$ weather index to estimate the contribution of climate to corn and soybean yields in the US. Boston (USA): AIR Worldwide Corporation. http://ageconsearch.umn.edu/bitstream/35613/1/ sp05zu01.pdf

AIR Worldwide Corporation, 2009. The AIR Multiple Peril Crop Insurance (MPCI) model for the US. Boston (USA): AIR Worldwide Corporation. http:// www.air-worldwide.com/publications/brochures/ documents/air-u-s-multiple-peril-crop-model-brochure

AIR Worldwide Corporation, 2011. The AIR Multiple Peril Crop Insurance (MPCI) model for China. Boston (USA): AIR Worldwide Corporation. http:// www.air-worldwide.com/publications/brochures/ documents/The-AIR-Multiple-Peril-Crop-InsuranceModel-for-China/

Aker J, 2008. Does digital divide or provide? The impact of cell phones on grain markets in Niger. Berkeley (USA): University of California. http:// www.cgdev.org/doc/events/2.12.08/Aker Job Market Paper 15jan08 2.pdf

Chapoto A, Govereh J, Haggblade S, Thomas J, 2010. Staple food prices in Zambia. International Development Working Paper. East Lansing (USA): Michigan State University, Department of Agricultural, Food and Resource Economics. http://ageconsearch.umn.edu/bitstream/58556/2/AAMP Maputo_23_Zambia_ppr.pdf

Collier B, Barnett B, Skees J, 2010. State of knowledge report - data requirements for the design of weather index insurance. Lexington (USA): GlobalAgRisk Inc. http://www.globalagrisk.com/ Pubs/2010 GlobalAgRisk State of Knowledge Data_sept.p̄pdf

FAO, 2005. Improving information flows to rural communities. Agricultural Management, Marketing and Finance Occasional Paper No 9. Rome (Italy): FAO. ftp://ftp.fao.org/docrep/fao/ 009/a0287e/a0287e00.pdf.

FARMDOC, 2013. Learn how people are using FARMDOC: farmer profile. Urbana-Champaign (USA): University of Illinois. http://www.farmdoc. illinois.edu/about/users farm.html

Ferris S, Engoru P, Caganzi E, 2008. Making market information systems work better for the poor in Uganda. CAPRI Working Paper No 77. Washington DC (USA): CGIAR Systemwide Program on Collective Action and Property Rights (CAPRi). http:// 
www.ifpri.org/sites/default/files/publications/ CAPRiWP77.pdf

Haggblade S, Longabaugh S, Tschirley D, 2009. Spatial patterns of food staple production and marketing in South East Africa: implications for trade policy and emergency response. Internationa Development Working Paper No 100. East Lansing (USA): Michigan State University, Department of Agricultural, Food and Resource Economics. http://ageconsearch.umn.edu/bitstream/54553/2/ idwp100.pdf

Jaffee S, Siegel P, Andrews C, 2010. Rapid agricultural supply chain risk assessment: a conceptual framework. Agriculture and Rural Development Discussion Paper No 47. Washington DC (USA): The World Bank. http://siteresources. worldbank.org/INTCOMRISMAN/Resources/RapApRiskAssessment_Framework_Final_Web.pdf

Jaffee S, Dana J, Manuamorn O, Bryla E, Syroka J Dick W, et al., 2008. The international task force on commodity risk management in developing countries: activities, findings and the way forward. Agriculture and Rural Development Discussion Paper. Washington DC (USA): The World Bank. http://siteresources.worldbank.org/INTCOMRISMAN/ Resources/ITF.pdf

Ker A, Goodwin B, 2000. Nonparametric estimation of crop insurance rates revisited. American Journal of Agricultural Economics 83 : 463-78.

Market Information Organization of the Americas MIOA, 2013. Directory of member countries market information systems. Washington DC (USA): MIOA. http://www.mioa.org/english/miembros.htm

Ramirez O, Sukant M, Field J, 2003. Crop-yield distributions revisited. American Journal of Agricultural Economics 85 : 108-20.

Sherrick B, Zanini F, Schnitkey G, Irwin S, 2004. Crop insurance valuation under alternative yield distributions. American Journal of Agricultural Economics 86(2):406-19.

Sistema de Información de Mercados de Productos Agrícolas de Honduras - SIMPAH, 2013. Reporte diario de precios de productos agricolas. La Lima (Honduras): FHIA. http://www.fhia.org.hn/htdocs/ simpah.html

Svensson J, Yanagizawa D, 2009. Getting prices right: impact of market information service in Uganda. Journal European Economic Association 7 (2-3). http://people.su.se/ jsven/SvenssonYanagizawa.pdf

Trostle R, 2008. Global agriculture supply and demand: factors contributing to the recent increase in food commodity prices. WRS-0801 Report. Washington DC (USA): U.S. Department of Agriculture, Economic Research Service. http://www. ers.usda.gov/publications/wrs-international-agriculture-and-trade-outlook/wrs-0801.aspx

Vergara O, Coble K, Knight T, Patrick G, Baquet A, 2004. Farm income variability and the supply of offfarm labor by limited-resource farmers. Journal of
Agricultural and Applied Economics 36 : 467-79. http://ageconsearch.umn.edu/bitstream/43394/2/ Vergara\%20JAAE \%20August \% 202004.pdf

Vergara O, Coble K, Hudson D, Knight T, Patrick G, Baquet A, 2005. Target markets for grain and cotton marketing consultants and market information systems. Journal of Agricultural and Resource Economics 30 : 167-83. http://ageconsearch.umn. edu/bitstream/30780/1/30010167.pdf

Vergara O, Zuba G, Doggett T, Seaquist J, 2008. Modeling the potential impact of catastrophic weather on crop insurance industry portfolio losses. American Journal of Agricultural Economics $90: 1256-62$.

Vos F, Rodriguez J, Below R, Guha-Sapir D, 2010. Annual disaster statistical review: the numbers and trends. Brussels (Belgium): CRED. http:// www.emdat.be/publication/annual-statistical-reviewnumbers-and-trends-2009

World Food Programme, 2012. WFP in Africa: 2012 facts, figures and partners. Rome (Italy): WFP. http://documents.wfp.org/stellent/groups/ public/documents/communications/wfp 257465 . pdf

Zambia National Farmers Union, 2013. Zambia meteorological department - crop weather bulletin highlights. Lusaka (Zambia): ZMD. http://www. zmd.gov.zm/ 